\title{
Determinan Nilai Pelanggan dan Implikasinya pada Kinerja Pemasaran Dealer Mobil SUV Premium
}

\author{
Aditya Wardhana \\ Fakultas Ekonomi, Universitas Nurtanio \\ J1. Padjajaran No. 219 Lanud. Husein S. Bandung \\ E-Mail: pesona.indonesia@yahoo.com
}

\begin{abstract}
This study examines the implementation of market strategy and marketing mix strategy and customer relationship management affecting the customer value and its implication on the marketing performances. In this research, market strategy includes market segmentation and targeting, positioning. Marketing mix strategy includes products, price, place, and promotion (4 Ps), while the marketing performance includes sales volume, profit, and the market share. This study uses survey research method, data were collected from 100 heads of authorized dealers premium SUV in West Java and Banten Proviences as respondents, with data analysis using path analysis. Based on the research results, it was concluded that the performance of marketing authorized dealer of premium SUVS in West Java and Banten Proviences influenced by customer value, and customer value is affected by the implementation of market strategy, marketing mix strategy and management of customer relationship management either partially or simultaneously.
\end{abstract}

Keywords: market strategy, marketing mix strategy, customer relationship management, customer value, marketing performance.

\begin{abstract}
ABSTRAK
Penelitian ini mengkaji bagaimana implementasi strategi pasar dan bauran pemasaran serta manajemen kerelasian pelanggan yang mempengaruhi nilai pelanggan dan implikasinya pada kinerja pemasaran. Implementasi strategi pasar meliputi segmentasi pasar, penargetan dan pemosisian. Strategi bauran pemasaran meliputi produk, harga, distribusi, dan promosi (4 Ps), sementara itu kinerja pemasaran meliputi volume penjualan, keuntungan, dan pangsa pasar. Penelitian ini menggunakan metode survei dengan data penelitian dikumpulkan dari dari 100 kepala dealer resmi mobil SUV premium di Propinsi Jawa Barat dan Banten sebagai responden, dengan analisis data menggunakan analisis jalur. Berdasarkan hasil penelitian, disimpulkan bahwa kinerja pemasaran dealer resmi mobil SUV premium di Propinsi Jawa Barat dan Banten dipengaruhi oleh nilai pelanggan, dan nilai pelanggan dipengaruhi oleh implementasi strategi pasar dan strategi bauran pemasaran serta manajemen kerelasian pelanggan baik secara parsial maupun simultan.
\end{abstract}

Kata Kunci: strategi pasar, strategi bauran pemasaran, manajemen kerelasian pelanggan, nilai pelanggan, kinerja pemasaran. 


\section{PENDAHULUAN}

Industri kendaraan bermotor di Indonesia mulai berkembang sejak beroperasinya Agen Tunggal Pemegang Merek (ATPM) pada awal tahun 1970-an yang didukung oleh Keputusan Menteri Perindustrian Nomor 295/M/SK/7/1982 tanggal 7 Juli 1982 tentang Ketentuan-ketentuan Keagenan Tunggal dan Keputusan Menteri Perindustrian Nomor 428/M/SK/12/1987 tanggal 23 Desember 1987 tentang Penyederhanaan Ketentuan-ketentuan Pengakuan dan Pengurangan Pengakuan Keagenan Tunggal Kendaraan Bermotor dan Alat-alat Besar serta Keagenan Tunggal Alat-alat Elektronika dan Alat-alat Listrik untuk Rumah Tangga.

Pemerintah pada tahun 2008 menerbitkan Peraturan Presiden Nomor 28 Tahun 2008 tentang Kebijakan Industri Nasional, dimana visi pembangunan industri nasional adalah menjadi negara industri tangguh pada tahun 2025, dengan visi antara pada tahun 2020 sebagai negara industri maju baru. Industri otomotif menjadi industri andalan masa depan yang menjadi basis industri manufaktur di Indonesia pada tahun 2025.

Kondisi pasar otomotif kendaraan roda empat di Indonesia terus meningkat dalam kurun waktu tahun 2000-2012 sebagaimana terlihat pada Gambar 1.
Sepanjang tahun 2012, perkembangan pasar otomotif nasional masih dikuasai oleh para ATPM yang merupakan pemain lama, seperti Astra Group (pangsa pasar 53,69\%), Indomobil Group (pangsa pasar $16,61 \%$ ), dan pangsa pasar sisanya sebesar 29,70\% dikuasai oleh beberapa ATPM antara lain, PT Honda Prospect Motor (Honda), PT Krama Yudha Tiga Berlian Motor (Mitsubishi), PT Mazda Motor Indonesia (Mazda), PT Ford Motor Indonesia (Ford), PT General Motor Auto World Indonesia (Chevrolet), PT Kia Mobil Indonesia (Kia), PT Hyundai Indonesia Motor (Hyundai), PT Auto Euro Indonesia (Renault), PT Proton Edar Indonesia (Proton), dan lain-lain.

Produk otomotif di Indonesia terbagi menjadi dua varian yaitu kendaraan penumpang dan kendaraan niaga. Kendaraan penumpang terbagi menjadi tiga jenis yaitu: Sedan, Multi Purpose Vehicle (MPV), dan Sport Utility Vehicle (SUV) yang masingmasing dibagi lagi berdasarkan besarnya kapasitas mesin. Sementara itu untuk kendaraan niaga terbagi menjadi tiga jenis yaitu: Bus, Pick Up/Truk, dan Double Cabin $4 \times 2 / 4 \times 4$ selanjutnya masing-masing jenis dibagi lagi berdasarkan berat kendaraan (gross vehicle weight).

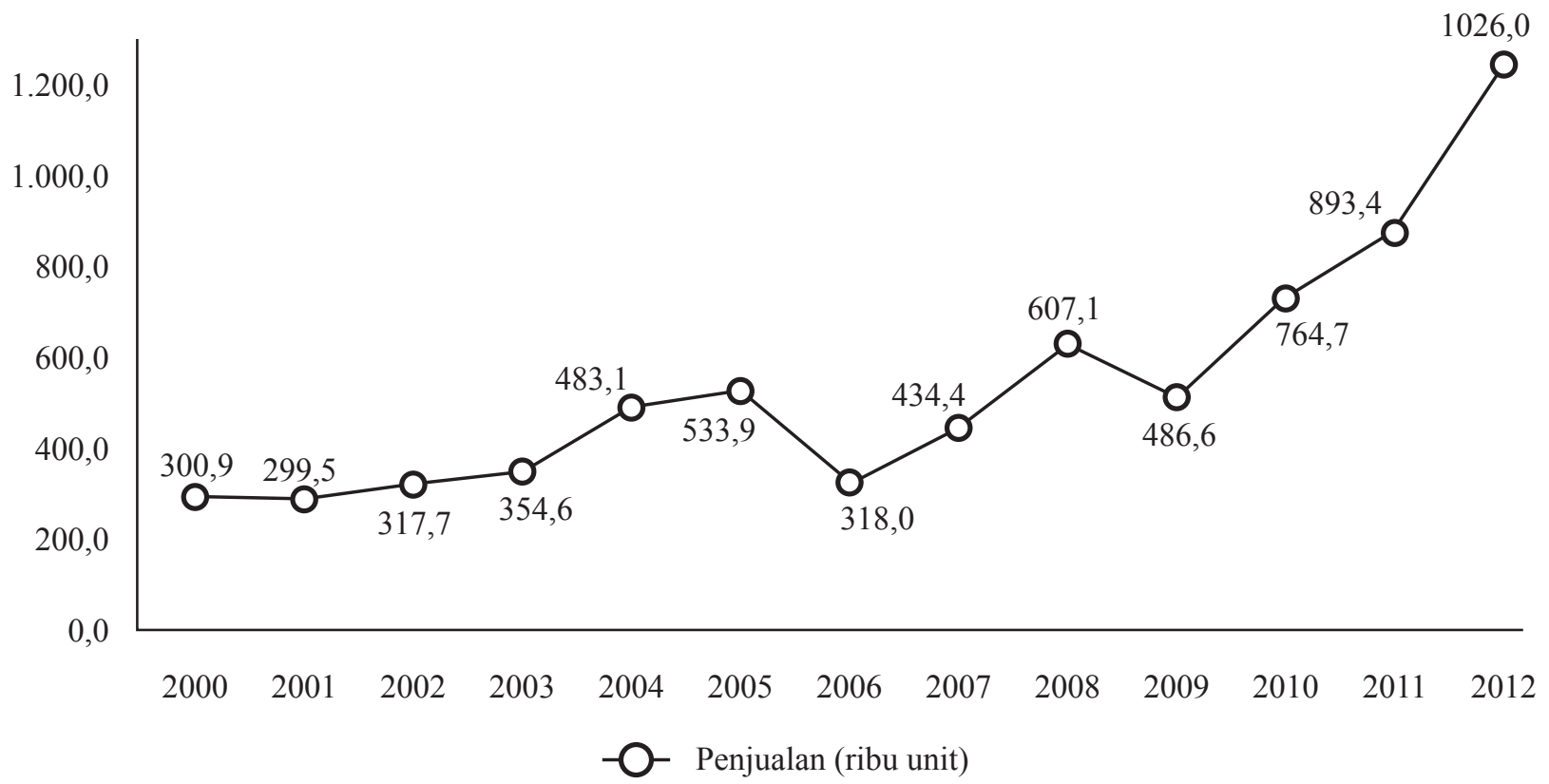

Sumber: Gaikindo, 2013

Gambar 1. Perkembangan Hasil Penjualan

Kendaraan Roda Empat Nasional 


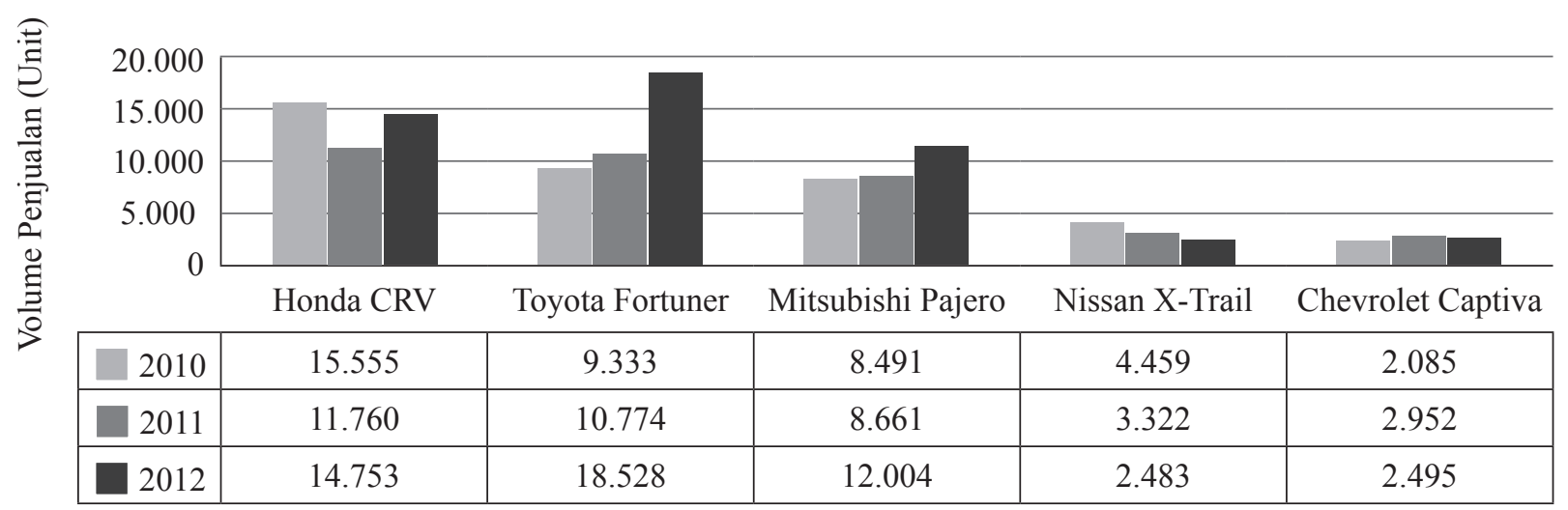

Sumber: Gaikindo, 2013

Gambar 2. Hasil Penjualan Peringkat Lima Besar Merek dan Jenis Kendaraan SUV Premium Tahun 2010-2012

Volume penjualan mobil masih didominansi oleh varian penumpang, sehingga trend pasar mobil nasional mengarah kepada MPV pada peringkat pertama (pangsa pasar 62\%), dan SUV pada peringkat kedua (pangsa pasar 17\%), dan sedan pada peringkat ketiga (pangsa pasar 4\%), sedangkan pangsa pasar untuk kendaraan niaga sebesar 17\% (Kompas, 13 April 2012).

Kendaraan jenis SUV diminati oleh para profesional, pengusaha maupun para eksekutif muda, karena SUV memiliki keunggulan dibandingkan jenis lainnya seperti: kabin yang lapang, desain bodi yang gagah, posisi mengemudi (ground clearance) yang tinggi, ketangguhan di segala medan dengan kinerja kaki-kaki yang lebih fleksibel pada berbagai kondisi jalan, dan kenyamanan berkendara seperti MPV dan sedan (Tanoso, 2012).

Dengan semakin meningkatnya kelas menengah di Indonesia dan kondisi infrastruktur jalan yang masih buruk di Indonesia, menjadi faktor pendorong bagi para ATPM untuk meraih angka penjualan tertinggi untuk varian kendaraan mobil jenis SUV ini (Soerono, 2012).

Hasil penjualan Peringkat Lima Besar Merek dan Jenis Kendaraan SUV Premium Tahun 2010-2012 dapat dijelaskan pada Gambar 2.

Minat konsumen terhadap kendaraan SUV premium secara nasional cenderung meningkat selama tiga tahun terakhir yaitu tahun 2010 sebanyak 39.923 unit, tahun 2011 sebanyak 37.469 unit, dan tahun 2012 sebanyak 50.263 unit (Gaikindo, 2013). Kenaikan minat konsumen pada kendaraan SUV premium didorong karena teknologi kenyamanan berkendara dan model yang fashionable yang ditawarkan oleh kelas SUV Premium ini sehingga dapat digunakan baik oleh pria maupun wanita.

Dengan semakin banyak kompetitor dan pemain baru di pasar SUV khususnya SUV Premium, semakin mendorong para ATPM untuk terus menerus memberikan pelayanan yang baik, produk yang semakin berkualitas, didukung oleh kecanggihan teknologi, berinovasi serta ramah lingkungan dengan harga yang kompetitif (Tanoso, 2012).

Berdasarkan data dari Gabungan Industri Kendaraan Bermotor Indonesia (Gaikindo), potensi pasar kendaraan bermotor roda empat di Jawa Barat cukup besar yaitu dengan pangsa pasar 18\% dari penjualan nasional serta didukung pula oleh keberadaan 100 dealer resmi dari lima ATPM SUV Premium terbesar yang tersebar di 17 kota/ kabupaten di Jawa Barat dan Banten.

Volume penjualan mobil di Jawa Barat selama tahun 2010 sebanyak 137.646 unit, tahun 2011 sebanyak 160.809 unit, tahun 2012 sebanyak 184.679 unit. Sedangkan porsi kendaraan SUV Premium di Jawa Barat selama tahun 2010 sebanyak 23.398 unit, tahun 2011 sebanyak 28.946 unit, dan tahun 2012 sebanyak 33.796 unit (Gaikindo dan Dispenda Jawa Barat dan Banten, Januari 2013).

Dengan semakin ketatnya persaingan tersebut, strategi pemasaran yang meliputi strategi pasar (segmentasi, target, dan pemosisian pasar) dan strategi bauran pemasaran (produk, harga, distribusi, dan promosi) akan memiliki peranan yang sangat penting dalam melihat berbagai peluang yang ada yang didukung pula oleh manajemen kerelasian 
pelanggan yang baik guna menjaga hubungan baik dan mempertahankan pelanggan sebagai aset yang bernilai dan menguntungkan bagi perusahaan (Kotler dan Keller, 2012). Perusahaan harus mampu menciptakan nilai yang superior bagi pelanggannya (Cravens, 2009) yang pada akhirnya akan mempengaruhi kinerja pemasarannya baik penjualan, profit, maupun pangsa pasar.

Pada organisasi yang mengelola beberapa perusahaan atau unit bisnis (diversified company) sekurang-kurangnya terdapat tiga tingkatan strategi, yaitu strategi tingkat korporasi (corporate level strategy), strategi unit bisnis (business level strategy), dan strategi fungsional (functional level strategy). Strategi pemasaran (marketing strategy) termasuk pada strategi tingkat fungsional bersama-sama dengan strategi fungsional lainnya seperti strategi keuangan, strategi operasional, strategi sumber daya manusia, dan lainnya (Kotler dan Amstrong, 2012:63).

Berdasarkan survei pendahuluan (preliminary research) bahwa masih rendahnya kinerja pemasaran atas produk SUV Premium yang diproduksi oleh ATPM karena nilai pelanggan yang masih rendah yang disebabkan oleh kurang efektifnya implementasi strategi pemasaran yang meliputi strategi pasar dan strategi bauran pemsaran dan manajemen kerelasian pelanggan yang dilakukan ATPM terhadap pelanggan produk SUV Premium yang berasal dari kelas sosial menengah atas (middle up class) dan kelas atas (upper class).

Kinerja pemasaran dealer resmi mobil SUV di Jawa Barat dan Banten selama tiga tahun terakhir cenderung menurun seperti pertumbuhan penjualan dari $23,72 \%$ menjadi $16,75 \%$, profit yang juga menurun dan pangsa pasar SUV yang stagnan pada kisaran $18 \%$ yang belum mencapai target yang ditetapkan ATPM sebesar $25 \%$ dari total penjualan mobil.

Secara umum masih banyak terdapat permasalahan yang terkait dengan nilai pelanggan terhadap dealer resmi kendaraan SUV Premium di Jawa Barat dan Banten seperti $60 \%$ pelanggan harus mengeluarkan pengorbanan ke lokasi dealer yang berada di kota/ kabupaten tertentu, 53\% pelanggan merasa pelayanan belum sesuai harapan, $33,33 \%$ pelanggan menyatakan citra dealer belum sesuai harapan, dan $27 \%$ merasa kesal menunggu untuk dilayani.

Di sisi lain, manajemen kereleasian pelanggan yang dilakukan pihak dealer resmi belum optimal mengingat masih terdapat berbagai kekurangan yang dirasakan pelanggan yaitu: (1) people, seperti kurangnya keterampilan karyawan bengkel, (2) process, seperti masih lambatnya waktu pelayanan, (3) technology, seperti belum dioptimalkannya dan tidakmeratanya penggunaan teknologi layanan pelanggan seperti layanan registrasi dan indent services, layanan customer complaints, layanan perawatan dan perbaikan dengan teknologi terbaru, dan lain sebagainya.

Ditinjau dari implementasi strategi segmenting, targeting, dan positioning (STP) dan strategi bauran pemasaran belum sepenuhnya mampu meraih pelanggan pada kelas sosial menengah atas dan kelas atas sebagaimana yang diharapkan baik oleh dealer resmi maupun ATPM SUV premium.

Berdasarkan uraian tersebut, implementasi strategi pemasaran dan manajemen kerelasian pelanggan yang dilakukan oleh ATPM perlu mendapat perhatian serius guna meningkatkan nilai pelanggan terhadap produk SUV Premium yang pada akhirnya dapat meningkatkan kinerja pemasarannya.

Berdasarkan uraian tersebur, maka dalam penelitian ini permasalahan yang ingin dikaji adalah apakah terdapat pengaruh implementasi strategi pasar dan strategi bauran pemsaran, serta manajemen kerelasian pelanggan terhadap nilai pelanggan baik secara parsial maupun simultan, serta apakah terdapat pengaruh nilai pelanggan terhadap kinerja pemasaran.

\section{METODE}

Metode yang digunakan dalam penelitian ini adalah metode survei dimana jenis penelitian adalah penelitian deskriptif dan verifikatif yang bertujuan untuk memberikan gambaran keterkaitan variabel penelitian dan menjawab permasalahan penelitian. Penelitian ini dilakukan untuk mendapatkan gambaran dan informasi mengenai implementasi strategi pasar (marketing strategy) dan strategi baruan pemasaran (marketing mix strategy), manajemen kerelasian pelanggan (customer relationship management), nilai pelanggan (customer value), dan kinerja pemasaran (marketing performance) produk SUV Premium dengan studi pada pelanggan SUV Premium di Jawa Barat. Penelitian ini juga dilakukan untuk mengetahui ada tidaknya hubungan sebab akibat antara variabel independen yaitu strategi pasar (marketing strategy) dan strategi baruan pemasaran (marketing mix strategy), manajemen kerelasian pelanggan (customer relationship management), dan 
variabel intervening yaitu nilai pelanggan (customer value), sedangkan variabel dependen adalah kinerja pemasaran (marketing performance) produk SUV Premium, seperti terlihat pada diagram paradigma penelitian. Pada penelitian ini time horizon datanya adalah cross sectional yang mencerminkan gambaran dari suatu waktu tertentu dan unit analisisnya adalah kepala dealer resmi mobil SUV Premium di Jawa Barat.
Untuk menjawab permasalahan dalam penelitian ini, variabel yang akan dianalisis terdiri atas: variabel bebas $\left(\mathrm{X}_{1}\right)$ strategi pasar (market strategy), variabel bebas $\left(\mathrm{X}_{2}\right)$ strategi bauran pemasaran (marketing mix strategy), manajemen kerelasian pelanggan $\left(\mathrm{X}_{3}\right)$, variabel intervening yaitu nilai pelanggan (Y), sedangkan variabel terikat (Z) adalah kinerja pemasaran (marketing performance).

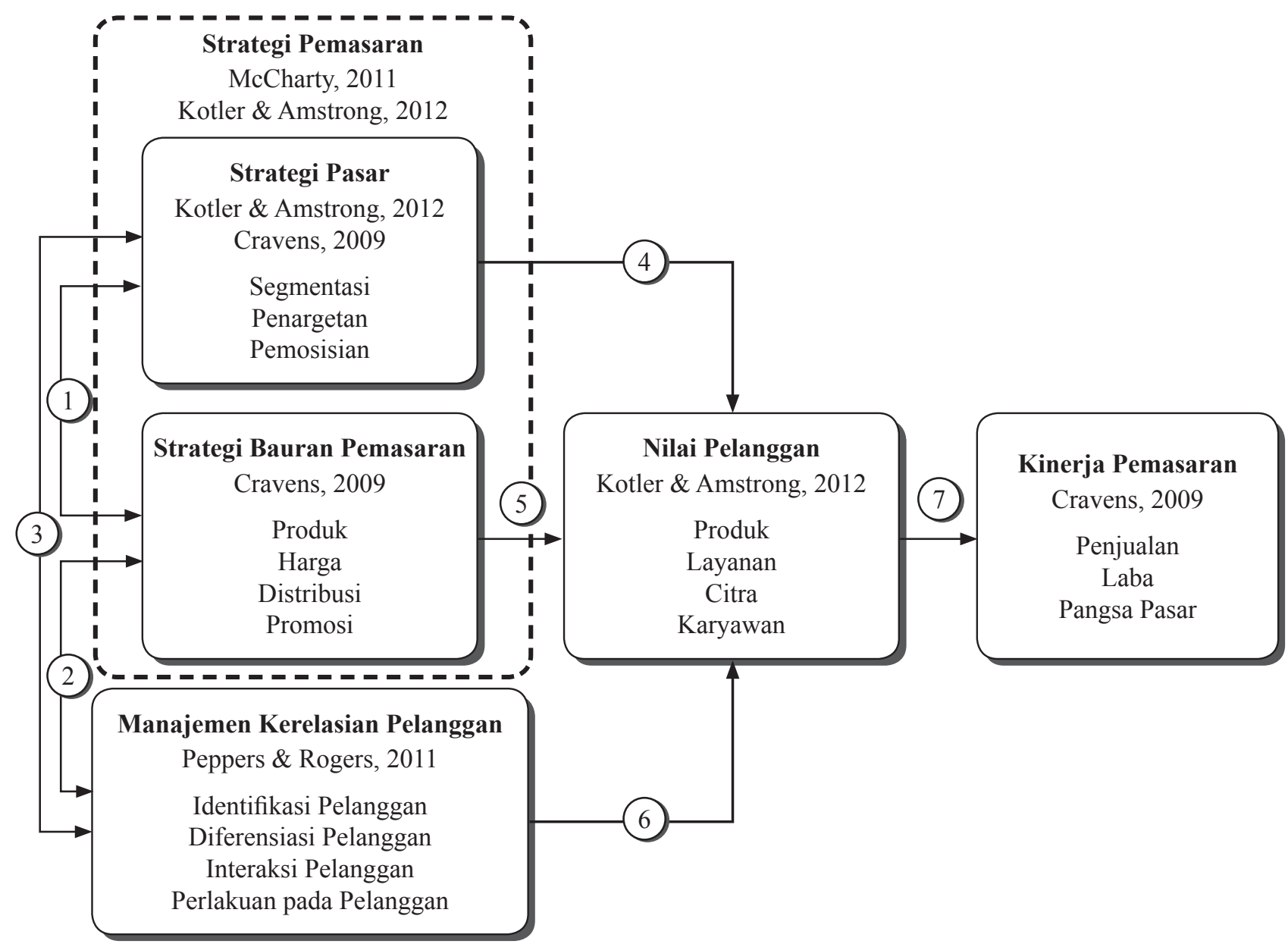

Keterangan Gambar:

1. Cravens (2009:194), Kotler \& Keller (2012:254), Mooradian (2012:2)

2. Kandampully (1998:435), Mooradian (2012:2)

3. Cravens (2009:167), Alipour \& Mohammadi (2011: 8, Devaraja (2012:19), Mooradian (2012:2)

4. Devaraja (2012:19), Cravens (2009:13), Cravens (2009:167), Kotler \& Amstrong (2012:72)

5. Cravens (2009:13), Cravens (2009:167), Kotler \& Amstrong (2012:72), Kotler \& Amstrong (2012:75), Kotler \& Amstrong (2012:315), Kotler \& Amstrong (2012:365)

6. Cravens (2009:217), Kandampully (1998: 434), Zineldin (2006: 330), Alipour \& Mohammadi (2011: 8), Payne \& Frow (2005: 170), McNaughton (2002: 12), Cravens (2009: 217), Peppers \& Rogers (2011: 34), Devaraja (2012:19), Sheth \& Parvatiyar (2001: 5), Storbacka \& Nenonen (2009), Kottler \& Keller (2009:15)

7. Peppers \& Rogers (2011: 5), Kotler \& Keller (2012: 147), Cravens (2009:7), He (2001: 1172), Ulaga (2001: 317), Day \& Melvin (2000: 55-57)

Gambar 3. Paradigma Penelitian 
Penentuan data dilakukan terhadap dealer resmi kendaraan SUV Premium di Jawa Barat yang termasuk dalam peringkat lima besar ATPM berdasarkan hasil penjualan kendaraan SUV Premium-nya yaitu sebanyak 100 dealer resmi di 17 kota/kabupaten di Jawa Barat dan Banten sebagai responden dalam penelitian ini adalah para kepala dealer kendaraan SUV Premium di Jawa Barat dan Banten berdasarkan wilayah area lokasi dealer yang terdiri dari Jawa Barat Bagian Utara (Bekasi, Depok, Karawang, Subang, Purwakarta), Bagian Selatan (Sukabumi, Garut, Tasikmalaya), Bagian Barat dan Banten (Cilegon, Serang, Bogor, Bandung, Cianjur), dan Bagian Timur (Sumedang, Cirebon, Jatibarang, Ciamis). Penelitian ini merupakan penelitian populasi dan bukan penelitian sampel.

Data primer berupa himpunan informasi yang diperoleh dari survei dengan metode observasi, wawancara, dan penggunaan kuesioner terstruktur bersifat tertutup yang menanyakan kepada responden tentang implementasi strategi pasar dan strategi bauran pemasaran, manajemen kerelasian pelanggan, nilai pelanggan, dan kinerja pemasaran. Data sekunder yang digunakan dalam penelitian, yaitu data yang diperoleh dari pihak dealer resmi SUV Premium milik ATPM di Jawa Barat dan Banten seperti data laporan kinerja, brosur, katalog, dan lain sebaginya dan juga data yang diperoleh dari pihak kedua berupa data hasil-hasil studi baik studi literatur maupun data dari Gabungan Industri Kendaraan Bermotor Indonesia (Gaikindo), Badan Pusat Statistik (BPS), Kementerian Perindustrian, dan lain sebagainya.

Hasil uji validitas (test of validity) instrumen penelitian variabel strategi pasar yang terdiri dari 16 pertanyaan, variabel strategi bauran pemasaran yang terdiri dari 37 pertanyaan, variabel manajemen kerelasian pelanggan yang terdiri dari 20 pertanyaan, variabel nilai pelanggan yang terdiri dari 16 pertanyaan, dan variabel kinerja pemasaran yang terdiri dari 3 pertanyaan menunjukkan bahwa tidak terdapat satupun nilai yang berada di bawah batas koefisien korelasi 0,30 sehingga seluruh pertanyaan kuesioner penelitian adalah valid.

Hasil uji reliabilitas (test of reliability) menggunakan koefisien Alpha Cronbach's diperoleh nilai koefisien Alpha Cronbach's sebesar 0,81 diatas 0,70 menunjukkan kuesioner yang digunakan reliabel.

Hasil pengujian normalitas data dengan menggunakan Chi Kuadrat untuk setiap variabel penelitian menunjukkan hasil bahwa data nilai statistik 100 responden tersebut dapat dinyatakan berdistribusi normal.

Hasil pengujian kelayakan model menunjukkan bahwa model penelitian telah memenuhi the goodness of econometric model atau karakteristik yang diharapkan, sehingga model tersebut layak untuk digunakan dalam penelitian yang sama pada waktu dan tempat yang berbeda.

Penelitian ini dianalisis dengan menggunakan analisis jalur (path analysis). Dalam analisis jalur memperhitungkan adanya pengaruh langsung dan tidak langsung. Pengaruh tidak langsung suatu variabel independen terhadap variabel dependen adalah melalui variabel intervening. Untuk menggambarkan hubungan kausalitas antar variabel yang diteliti pada penelitian ini digunakan diagram jalur (path diagram. Adapun penjelasan persamaan jalur dalam penelitian ini dapat diuraikan pada Gambar 4.

Persamaan struktural:

$\mathrm{Y}=\rho_{\mathrm{Y}} \mathrm{X}_{1} \mathrm{X}_{1}+\rho_{\mathrm{Y}} \mathrm{X}_{2} \mathrm{X}_{2}+\rho_{\mathrm{Y}} \mathrm{X}_{3} \mathrm{X}_{3}+\varepsilon_{1}$

$\mathrm{Z}=\rho_{\mathrm{ZY}} \mathrm{Y}+\varepsilon_{2}$

di mana:

$\mathrm{Y}=$ Nilai Pelanggan

$\mathrm{X}_{1}=$ Strategi pasar

$\mathrm{X}_{2}=$ Strategi Bauran Pemasaran

$\mathrm{X}_{3}=$ Manajemen Kerelasian Pelanggan

$\varepsilon_{1}=$ Pengaruh variabel lain diluar struktur model 1

$\varepsilon_{2}=$ Pengaruh variabel lain diluar struktur model 2

\section{Hipotesis Penelitian}

Berdasarkan kerangka pemikiran dan permasalahan penelitian, maka dapat dirumuskan hipotesis sebagai berikut (1) strategi pasar dan strategi bauran pemasaran serta manajemen kerelasian pelanggan berpengaruh terhadap penciptaan nilai pelanggan secara parsial, (2) strategi pasar dan strategi bauran pemasaran serta manajemen kerelasian pelanggan berpengaruh terhadap penciptaan nilai pelanggan secara simultan, dan (3) nilai pelanggan berpengaruh terhadap kinerja pemasaran. 


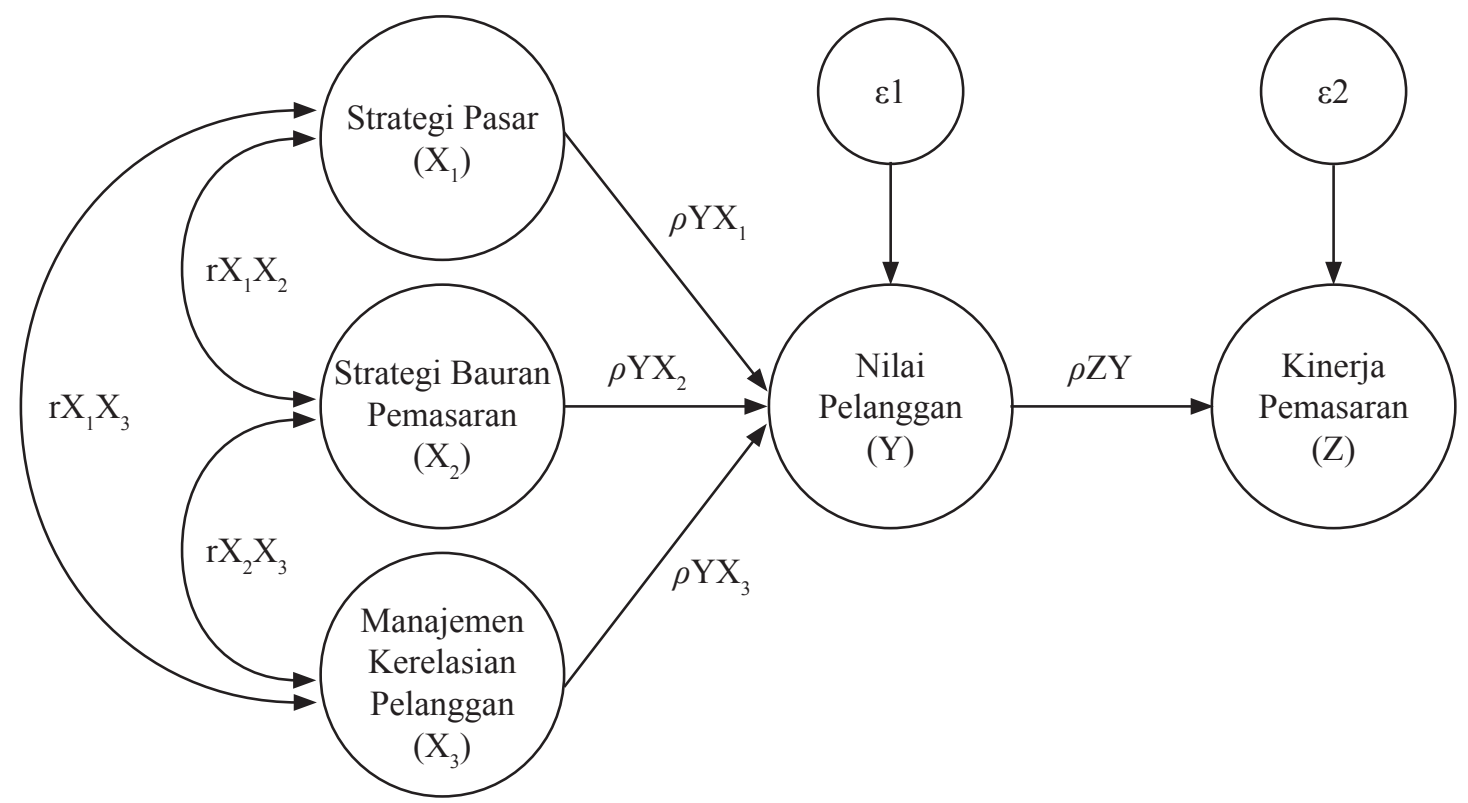

Gambar 4. Diagram Model Penelitian

\section{Pengujian Hipotesis}

Untuk menguji hipotesis dilakukan melalui hipotesis statistik dengan menggunakan analisis jalur sebagai berikut:

1. Untuk menguji hipoteis tentang adanya pengaruh secara parsial dari variabel $\mathrm{X}$ terhadap $\mathrm{Y}$ :

$\mathrm{H}_{0}: \rho \mathrm{YXi}=0$, artinya bahwa tidak ada pengaruh variabel Xi terhadap Y

$\mathrm{H}_{1}: \rho_{\mathrm{YXi}} \neq 0$, artinya bahwa terdapat ada pengaruh variabel Xi terhadap Y

di mana $i=1,2,3$.

Kriteria uji: tolak $\mathrm{H}_{0}$ jika $\mathrm{t}_{\text {hitung }}>\mathrm{t}_{\text {tabel }}$

2. Untuk menguji hipoteis tentang adanya pengaruh secara simultan dari variabel $\mathrm{X}$ terhadap $\mathrm{Y}$ :

$\mathrm{H}_{0}: \rho_{\mathrm{Yx} 1}=\rho_{\mathrm{Yx} 2}=\rho_{\mathrm{Yx} 3}=0$, artinya bahwa tidak ada pengaruh simultan dan signifikan variabel Xi terhadap $\mathrm{Y}$

$\mathrm{H}_{1}: \rho_{\mathrm{Yx} 1} \neq \rho_{\mathrm{Yx} 2} \neq \rho_{\mathrm{Yx} 3} \neq 0$, artinya bahwa terdapat pengaruh simultan dan signifikan variabel Xi terhadap Y

di mana $i=1,2,3$.

Kriteria uji: tolak $\mathrm{H}_{0}$ jika $\mathrm{F}_{\text {hitung }}>\mathrm{F}_{\text {tabel }}$

3. Untuk menguji hipoteis tentang adanya pengaruh dari variabel $\mathrm{Y}$ terhadap $\mathrm{Z}$ :

$\mathrm{H}_{0}: \rho_{\mathrm{ZY}}=0$, artinya bahwa tidak ada pengaruh variabel $Y$ terhadap $Z$

$\mathrm{H}_{1}: \rho_{\mathrm{ZY}} \neq 0$, artinya bahwa terdapat pengaruh variabel $\mathrm{Y}$ terhadap $\mathrm{Z}$

di mana $i=1,2,3$.

Kriteria uji: tolak $\mathrm{H}_{0}$ jika $\mathrm{F}_{\text {hitung }}>\mathrm{F}_{\text {tabel }}$

\section{HASIL}

Berdasarkan hasil perhitungan analisis jalur diperoleh korelasi yang positif di antara ketiga variabel bebas, yaitu antara strategi pasar, strategi bauran pemasaran, dan manajemen kerelasian pelanggan. Adapaun derajat hubungan dalam kategori rendah.

Berdasarkan hasil perhitungan analisis jalur dan hasil pengujian hipotesis secara parsial dari variabel $\mathrm{X}$ (startegi pasar, strategi bauran pemasaran, dan manajemen kerelasian pelanggan) terhadap variabel Y (nilai pelanggan), maka dapat disimpulkan bahwa ketiga variabel $\mathrm{X}$ tersebut secara parsial memberikan pengaruh yang signifikan. Dari total besaran pengaruh variabel $X$ tersebut, maka variabel strategi pasar memiliki pengaruh langsung terbesar terhadap penciptaan nilai pelanggan dibandingkan variabel bauran pemasaran maupun variabel manajemen kerelasian pelanggan.

Besaran koefisien jalur dari masing-masing variabel bebas terhadap variabel terikat dapat dilihat pada Tabel 1 .

Tabel 1. Koefisien Jalur Variabel X terhadap Variabel Y

\begin{tabular}{lc}
\hline \multicolumn{1}{c}{ Variabel } & Koefisien Jalur \\
\hline Strategi Pasar $\left(\mathrm{X}_{1}\right)$ & 0,243 \\
Strategi Bauran Pemasaran $\left(\mathrm{X}_{2}\right)$ & 0,236 \\
Manajemen Kerelasian Pelanggan $\left(\mathrm{X}_{3}\right)$ & 0,193 \\
\hline
\end{tabular}

Sumber: Hasil Pengolahan Data 
Berdasarkan Tabel 1. maka dapat diperoleh persamaan jalur sebagai berikut:

$\mathrm{Y}=0,243 \mathrm{X}_{1}+0,236 \mathrm{X}_{2}+0,193 \mathrm{X}_{3}+\varepsilon_{1}$

Urutan besaran pengaruh dari masing-masing variabel X terhadap Y dapat dilihat pada Tabel 2.

Tabel 2. Besaran Pengaruh Langsung dan Tidak Langsung Variabel X terhadap Variabel Y

\begin{tabular}{|c|c|c|c|c|c|c|}
\hline \multirow[t]{2}{*}{ Var } & \multirow{2}{*}{$\begin{array}{l}\text { Pengaruh } \\
\text { Langsung }\end{array}$} & \multicolumn{3}{|c|}{$\begin{array}{l}\text { Pengaruh Tidak } \\
\text { Langsung }\end{array}$} & \multirow{2}{*}{$\begin{array}{c}\text { Total } \\
\text { Pengaruh } \\
\text { Tidak } \\
\text { Langsung }\end{array}$} & \multirow{2}{*}{$\begin{array}{c}\text { Total } \\
\text { Pengaruh } \\
\text { Langsung } \\
\text { dan Tidak } \\
\text { Langsung }\end{array}$} \\
\hline & & $x_{1}$ & $x_{2}$ & $x_{3}$ & & \\
\hline$x_{1}$ & 0,0590 & & 0,069 & 0,057 & 0,126 & 0,311 \\
\hline$x_{2}$ & 0,0557 & 0,067 & & 0,056 & 0,122 & 0,300 \\
\hline$x_{3}$ & 0,0372 & 0,040 & 0,046 & & 0,085 & 0,208 \\
\hline \multicolumn{6}{|c|}{ Total Pengaruh $\mathrm{X}$ terhadap $\mathrm{Y}$} & 0,819 \\
\hline
\end{tabular}

Sumber: Hasil Pengolahan Data

Pengujian hipotesis parsial pengaruh variabel $\mathrm{X}$ terhadap variabel Y dapat diringkas dalam Tabel 3.

Tabel 3. Ringkasan Pengujian Koefisien Jalur X terhadap Y

\begin{tabular}{lllll}
\hline Struktural & $\begin{array}{c}\text { Koefisien } \\
\text { Jalur }\end{array}$ & Nilai $\mathbf{t}_{\text {hitung }}$ & Nilai $_{\text {tabel }}$ & Kesimpulan \\
\hline$\rho_{Y \times 1}$ & 0,243 & 7,267 & 1,98 & Signifikan \\
$\rho_{Y \times 2}$ & 0,236 & 5,614 & 1,98 & Signifikan \\
$\rho_{Y \times 3}$ & 0,193 & 2,999 & 1,98 & Signifikan \\
\hline
\end{tabular}

Sumber: Hasil Pengolahan Data

Strategi pasar berpengaruh secara signifikan terhadap nilai pelanggan. Pengaruh langsung variabel strategi pasar terhadap nilai pelanggan sebesar 5,90\% dan pengaruh tidak langsung sebesar 12,6\%.

Strategi bauran pemasaran berpengaruh secara signifikan terhadap nilai pelanggan. Pengaruh variabel strategi bauran pemasaran terhadap nilai pelanggan sebesar $5,57 \%$ dan pengaruh tidak langsung sebesar $12,2 \%$. Manajemen kerelasian pelanggan berpengaruh secara signifikan terhadap nilai pelanggan. Pengaruh variabel manajemen kerelasian pelanggan terhadap nilai pelanggan sebesar 3,72\% dan pengaruh tidak langsung sebesar $8,5 \%$.

Pengujian hipotesis simultan pengaruh variabel $\mathrm{X}$ terhadap variabel Y dapat diringkas dalam Tabel 4.
Tabel 4. Ringkasan Pengujian Simultan Varibel X terhadap Y

\begin{tabular}{lcllll}
\hline \multicolumn{1}{c}{ Model } & $\begin{array}{c}\text { Sum of } \\
\text { Squares }\end{array}$ & DF & $\begin{array}{c}\text { Mean } \\
\text { Square }\end{array}$ & F & Sig. \\
\hline 1 & 7051,573 & 3 & 1762,893 & 57,452 &, $000^{a}$ \\
Regression & 3395,792 & 97 & 10,228 & & \\
Residual & 10447,365 & 100 & & & \\
Total & & & & & \\
\hline
\end{tabular}

Sumber: Hasil Pengolahan Data

Berdasarkan Tabel 4. terlihat bahwa Fhitung adalah 57,432. Tingkat $\alpha=5 \%$ diperoleh nilai Ftabel adalah. $(57,432>2,70)$ atau nilai signifikansi 0,000 $<0,05$ maka H0 ditolak. Dengan demikian strategi pasar, strategi bauran pemasaran, dan manajemen kerelasian pelanggan berpengaruh secara simultan dan signifikan terhadap nilai pelanggan sebesar $81,9 \%$ sedangkan pengaruh variabel lain diluar model adalah sebesar $18,1 \%$.

Adapun persamaan jalur untuk variabel $\mathrm{Y}$ terhadap $Z$ yaitu: $Z=0,889 Y+\varepsilon_{2}$. Pengujian hipotesis parsial pengaruh variabel $Y$ terhadap variabel $Z$ dapat diringkas dalam Tabel 5.

Tabel 5. Ringkasan Pengujian Koefisien Jalur Y terhadap Z

\begin{tabular}{|c|c|c|c|c|}
\hline Struktural & Koefisien Jalur & Nilai $\mathbf{t}_{\text {hitung }}$ & Nilai $\mathbf{t}_{\text {tabel }}$ & Kesimpulan \\
\hline$\rho_{\mathrm{ZY}}$ & 0,889 & 29,42 & 1,98 & Signifikan \\
\hline
\end{tabular}

Sumber: Hasil Pengolahan Data

Nilai pelanggan berpengaruh secara signifikan terhadap kinerja pemasaran sebesar 79,03\% sedangkan pengaruh variabel lain diluar model adalah 20,97\%, seperti terlihat pada Gambar 5.

\section{PEMBAHASAN}

Berdasarkan hasil perhitungan analisis jalur dan hasil pengujian hipotesis secara parsial dari variabel strategi pasar, strategi bauran pemasaran, dan manajemen kerelasian pelanggan, maka dapat disimpulkan bahwa ketiga variabel bebas tersebut memberikan pengaruh yang signifikan terhadap nilai pelanggan. Strategi pasar merupakan variabel yang memberikan pengaruh terbesar terhadap nilai pelanggan dibandingkan dengan variabel lainnya. 


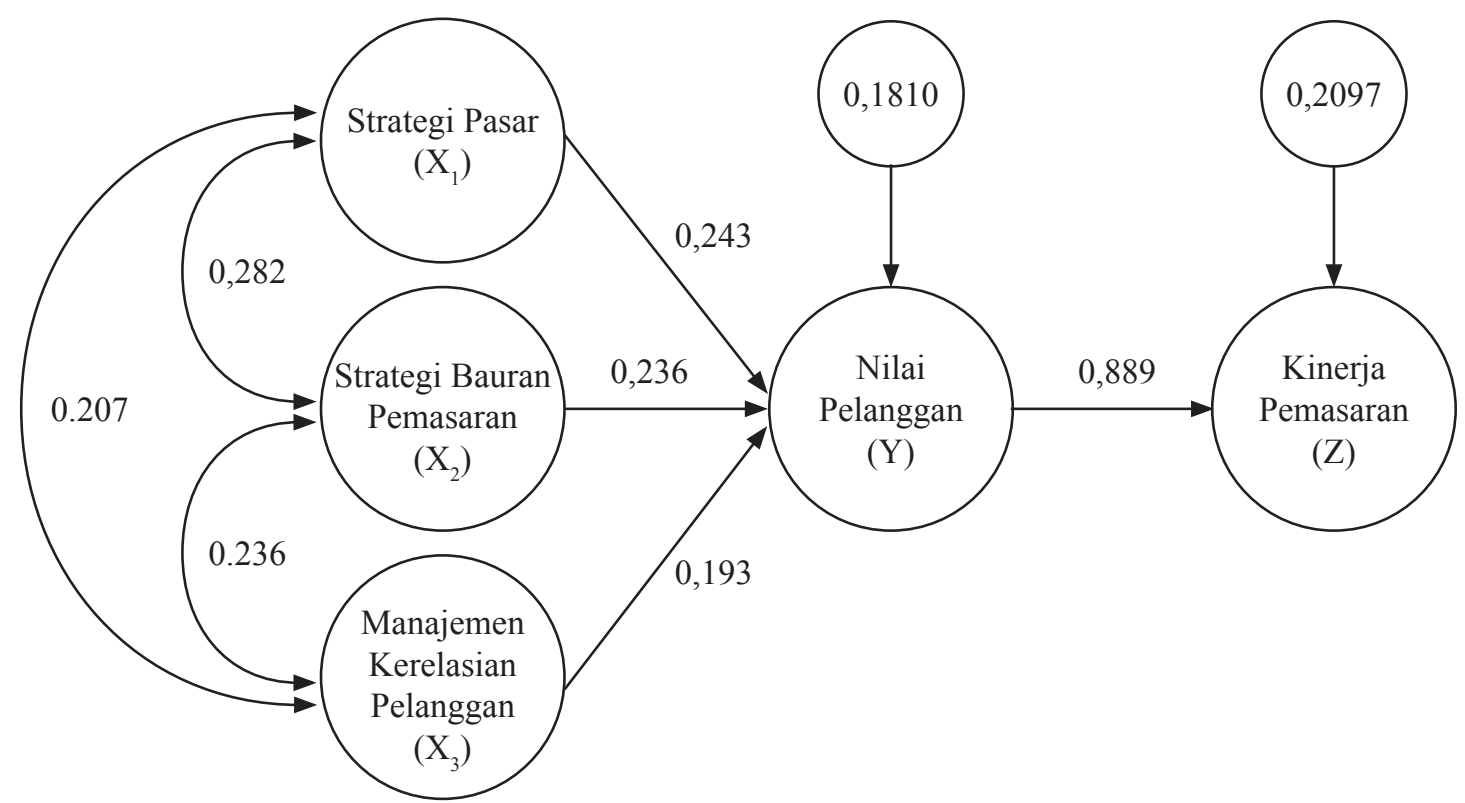

Gambar 5. Diagram Hasil Penelitian

Hal ini dapat dipahami karena strategi pasar yang tepat akan mampu mengoptimalkan nilai pelanggan. Hal ini sejalan dengan beberapa teori seperti yang dikemukakan oleh Cravens (2009:167) yang menyatakan bahwa implementasi strategi pasar (segmenting, targeting, positioning) dan strategi bauran pemasaran (4 Ps) adalah akan berhubungan dengan manajemen kerelasian pelanggan guna menciptakan nilai pelanggan. Mooradian (2012:40) menyatakan bahwa terdapat tiga hal yang saling berhubungan yaitu: (1) segmenting, targeting, positioning (STP); (2) marketing mix; dan (3) customer relationship management (CRM).

Variabel yang memiliki pengaruh terkecil adalah manajemen kerelasian pelanggan. Hal ini dapat dipahami mengingat manajemen kerelasian pelanggan belum sepenuhnya dioptimalkan penerapannya dalam meningkatkan nilai pelanggan mengingat keterbatasan orang, proses, dan teknologi yang dimiliki setiap dealer resmi yang menjadi objek penelitian ini. Sementara itu dalam beberapa literatur disebutkan bahwa manajemen kerelasian pelanggan merupakan hubungan yang kooperatif antara penyedia jasa dengan pelanggan yang bertujuan guna menciptakan nilai pelanggan yang superior (Zikmund, 2003:3). Selanjutnya Kottler dan Keller (2009:15) menyatakan bahwa manajemen kerelasian pelanggan akan membangun hubungan pelanggan yang langgeng dalam menciptakan nilai dan kepuasan pelanggan yang unggul. Cravens (2009:217), dan Kandampully (1998:434) menyatakan bahwa manajemen kerelasian pelanggan akan meningkatkan kinerja pemasaran bagi penyedia jasa karena perusahaan menjadi lebih selektif dalam memilih pelanggan mana yang akan perusahaan layani. Perusahaan menggunakan manajemen kerelasian pelanggan untuk mempertahankan pelanggan yang sudah ada sekaligus untuk membangun hubungan jangka panjang yang menguntungkan bagi perusahaan yang berdampak pada peningkatan kinerja pemasarannya.

Berdasarkan hasil perhitungan analisis jalur dan hasil pengujian hipotesis secara simultan dari variabel strategi pasar, strategi bauran pemasaran, dan manajemen kerelasian pelanggan terhadap nilai pelanggan, maka dapat disimpulkan ketiga variabel bebas tersebut memberikan pengaruh yang signifikan sebesar $79,7 \%$. Hasil penelitian ini sejalan dengan teori yang dikemukakan oleh Cravens (2009:167) dan Mooradian (2012:40) di mana implementasi strategi pasar (segmenting, targeting, positioning) dan strategi bauran pemasaran (4 Ps) dan manajemen kerelasian pelanggan adalah saling berhubungan guna menciptakan nilai pelanggan. Aspek dari manajemen kerelasian adalah bahwa peningkatan nilai tambah dapat dilakukan melalui hubungan saling ketergantungan dan kolaborasi yang bersifat saling menguntungkan antara penjual dan pembeli (Sheth, Jagdish N. and Parvatiyar, Atul, 2001). 
Nilai yang diterima berdasarkan persepsi pelanggan adalah evaluasi pelanggan pontensial terhadap perbedaan antara semua manfaat dengan semua biaya dari suatu penawaran yang dirasakan dan alternatif lainnya (Kotler dan Keller, 2012: 147). Total manfaat pelanggan adalah nilai moneter yang dirasakan dari sekumpulan manfaat ekonomi, fungsional, dan psikologis yang diharapkan pelanggan dari penawaran di pasar tertentu karena produknya, layanan, orang, dan citra. Total biaya pelanggan adalah yang sekumpulan biaya yang dirasakan pelanggan yang diterimmanya dalam mengevaluasi, memperoleh, menggunakan, dan membuang dari penawaran yang diberikan oleh pasar, termasuk uang, waktu, energi, dan biaya psikologis.

Dari pernyataan Cravens (2009:7) disimpulkan bahwa nilai untuk pembeli (nilai yang dirasakan oleh pembeli) terdiri dari manfaat dan biaya yang dihasilkan dari pembelian dan penggunaan produk. Nilai yang unggul terjadi ketika ada manfaat bersih yang positif. Nilai pelanggan yang unggul sebagai hasil dari suatu pengalaman dalam menggunakan yang sangat menguntungkan dibandingkan dengan harapan dan nilai yang ditawarkan pesaing. Di lain pihak hasil penelitian Hanny N. Nasution, dan Felix T. Mavondo (2008) menunjukkan bahwa persepsi manajer perusahaan terhadap nilai pelanggan yang satu dengan perusahaan lainya berbeda, tergantung dari pengalaman konsumennya masing-masing.

Penelitian yang dilakukan oleh He (2001:1172) menyimpulkan bahwa terdapat dua faktor yang mendasari preferensi pelanggan terhadap atributatribut nilai dari suatu produk yaitu faktor kesukaan (interest factor) dan faktor biaya (cost factor) Persepsi pelanggan terhadap nilai terutama timbul karena adanya perbedaan antara pengorbanan dan manfaat sebagaimana teori Kotler tentang nilai yang diterima pelanggan (customer delivered value). Nilai yang diterima pelanggan mengindikasikan adanya perbedaan dalam nilai produk yang diterima pelanggan dalam kondisi persaingan yang intensif dari nilai produk lainnya yang ditawarkan pesaing.

Berdasarkan hasil analisis data yang menghitung besaran pengaruh dan pengujian hipotesis nilai pelanggan terhadap kinerja pemasaran, maka diperoleh besaran pengaruhnya sebesar 79,03\% dan signifikan. Dengan demikian menunjukkan bahwa nilaipelangganmemberikankontribusiyang signifikan dalam meningkatkan kinerja pemasaran dealer resmi mobil SUV premium di Propinsi Jawa Barat dan
Banten. Hasil penelitian ini sejalan dengan teori yang dikemukakan oleh Peppers dan Rogers (2011:5), Kotler dan Keller (2012:147), Cravens (2009:7), He (2001:1172), Ulaga (2001:317), Storbacka dan Nenonen (2009), Payne, Adrian (2005), dan Day dan Melvin (2000:55-57) di mana peningkatan nilai pelanggan yang superior akan bisa memperbaiki kinerja pemasaran perusahaan, khususnya dalam hal ini adalah peningkatan pertumbuhan portofolio, pertumbuhan pendapatan, laba, maupun valuasi pasar.

\section{KESIMPULAN}

Hasil penelitian tentang pengaruh implementasi strategi pasar dan strategi bauran pemasaran serta manajemen kerelasian pelanggan terhadap nilai pelanggan dan implikasinya terhadap kinerja pemasaran dealer mobil SUV Premium di Propinsi Jawa Barat dan Banten diperoleh beberapa kesimpulan bahwa implementasi strategi pasar dan strategi bauran pemasaran, serta manajemen kerelasian pelanggan berpengaruh secara parsial dan signifikan terhadap nilai pelanggan dealer resmi mobil SUV premium di Propinsi Jawa Barat dan Banten. Pengaruh strategi pasar terhadap nilai pelanggan lebih besar dibandingkan dengan strategi bauran pemasaran maupun manajemen kerelasian pelanggan. Implementasi strategi pasar dan strategi bauran pemsaaran, serta manajemen kerelasian pelanggan berpengaruh secara simultan dan signifikan terhadap nilai pelanggan dealer resmi mobil SUV premium di Propinsi Jawa Barat dan Banten.

Hal ini berarti dengan semakin baiknya implementasi strategi pasar (STP) dan implementasi strategi bauran pemasaran (4 Ps) yang didukung oleh manajemen kerelasian yang semakin baik, maka akan meningkatkan nilai yang dirasakan pelanggan terhadap keberadaan produk dan dealer resmi ATPM. Besaran pengaruh strategi pasar dan strategi bauran pemsaaran, serta manajemen kerelasian pelanggan terhadap nilai pelanggan dealer resmi mobil SUV premium di Propinsi Jawa Barat dan Banten lebih besar dibandingkan dengan besarnya pengaruh vaiabel lainnya.

Nilai pelanggan berpengaruh secara signifikan terhadap kinerja pemasaran dealer resmi mobil SUV premium di Propinsi Jawa Barat dan Banten. Pengaruh nilai pelanggan terhadap kinerja pemasaran lebih besar dibandingkan variabel lainnya. Dengan 
demikian peningkatan nilai pelanggan yang superior akan bisa memperbaiki kinerja pemasaran perusahaan, khususnya dalam hal ini adalah peningkatan pertumbuhan portofolio, pertumbuhan pendapatan, laba, maupun valuasi pasar.

\section{DAFTAR PUSTAKA}

Alipour, Mehrdad and Mohammadi Hallaj Mohammad. 2011. The Effect of Customer Relationship Management (CRM) on Achieving Competitive Advantage of Manufacturing Tractor. Global Journal of Management and Business Research, 11(5): 1-9.

Barnes, James G. 2001. Secrets of Customer Relationship Management ( $1^{\text {st }}$ edition). Singapore: McGraw Hill.

Bull, Christopher. 2003. Strategic Issues in Customer Relationship Management (CRM) Implementation. Business Process Management Journal, 9(5): 592-602.

Canon, P. Joseph et al., 2011. Basic Marketing (18 ${ }^{\text {th }}$ edition). New York: McGraw Hill/Irwin.

Cravens, W. David. and Piercy, F. Nigel. 2009. Strategic Marketing ( $9^{\text {th }}$ edition). Singapore: McGraw Hill/Irwin.

Day, Ellen. and Crask, R, Melvin. 2000. Value Assessment: The Antecedent of Customer Satisfaction. Journal of Consumer Satisfaction, Dissatisfaction, and Complaining Behavior, 13: 52-60.

Devaraja, T. S. 2012. An Overview of Customer Relationship Management and Customer Value in Information Technology Industry. Working Paper at University of Mysore-India, 1-27.

Gaikindo dan Dispenda Jawa Barat dan Banten. 2013. Laporan Kendaraan Bermotor 2010-2012. Bandung.

Gronross, Christian. 2006. On defining marketing: finding a New Roadmap for Marketing. Marketing Theory Sage Publication, 6(4): 395-417.

He, Gao. 2001. Research on The Measurement of Customer Value: The Cas fo Cell Phone Industry. Industrial Marketing Management, 30: 339-351.

Kandampully, Jay. 1998. Service Quality to Service Loyalty: A Relationship Wich Goes Beyond Customer Services. Total Quality Management, 9(6): 431-443.
Kottler, Philip. and Amstrong, Gary. 2012. Principles of Marketing (14 ${ }^{\text {th }}$ Edition). New York: Pearson Educated Limited.

Kottler, Philip. and Keller, L. Kevin. 2012. Marketing Management (14 ${ }^{\text {th }}$ Edition). New York: Pearson Educated Limited.

McNaughton, Rod B. Osborn, Phil. and Imrie, C Brian. 2002. Market Oriented Value Creation in Service Firms. Working Paper at University of Waterloo-Canada.

Mooradian, A. Todd., et al. 2012. Strategic Marketing $\left(1^{\text {st }}\right.$ Edition). New Jersey: Pearson Education.

Nasution, Hanny H. and Mavobdo, Felix T. 2008. Customer Value in The Hotel Industry: What Managers Believe They Deliver and What Customer Experience. International Journal of Hospitality Management, 27(2): 204-213.

Payne, Adrian and Pennie Frow. 2005. A Strategic Framework for Customer Relationship Management. Journal of Marketing, 69: 167-176.

Peppers, Don. and Rogers, Martha. 2011. Managing Customer Relationships: A Strategic Framework ( $2^{\text {nd }}$ Edition). New Jersey: John Willey \& Sons.

Sheth, Jagdish N. and Parvatiyar, Atul. 2001. Customer Relationship Management: Emerging Practice, Process, and Discipline. Journal of Economic and Social Research, 3(2): 1-34.

Slater, F. S., and Narver, C. J. 1995. Market Orientation and The Learning Organization. Journal of Marketing, 59.

Smith, Brock J. and Colgate, Mark. 2007. Customer Value Creation. Jornal of Marketing Theory and Practice, 15(1): 7-23.

Soerono, Agus. 2012. Kemajuan Industri Otomotif Indonesia [Online], 15(12):12 Tersedia: http:// www.neraca.co.id/harian/article/22763 Desember 2012].

Storbacka, Kaj and Nenonen, Suvi. 2009. Customer Relationships and the Heterogeneity of Firm Performance. Journal of Business \& Industrial Marketing, 24: 360-372.

Tanoso, Harry. 2012. Ini Alasan Kenapa Honda CRV Merajai SUV di Indonesia. [Online], 25(7):12. Tersedia: http://www.marketing.co.id/ blog/2012/07/25.

Ulaga, Wolfgang. 2001. Customer Value in Business Market. Industrial Marketing Management, (30): 315-319. 
Wahyuningsih. 2004. Customer Value: Concept, Operationalization, and Outcome. Usahawan, 33 (28): 3-10.

Zeithaml, A. Valarie. Bitner, J. Mary. and Gremler, D. Dwayne. 2009. Services Marketing: Integrating Customer Focus Across the Firm (5 ${ }^{\text {th }}$ Edition). Singapore: McGraw Hill/Irwin.
Zikmund, G. William. and Babin, J. Barry. 2010. Exploring Marketing Research (10 ${ }^{\text {th }}$ Edition). New York: Cengange.

Zineldin, Mosad. 2006. Quality and Customer Relationship Management (CRM) as Competitive Strategy in The Swedish Banking Industry. The TQM Magazine, 17(4): 329-344. 